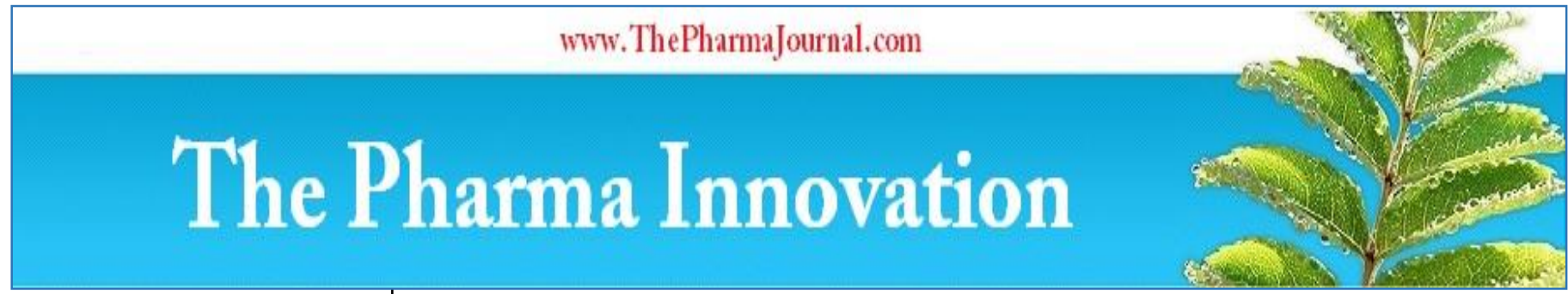

ISSN (E): 2277 - 7695

ISSN (P): 2349-8242

NAAS Rating: 5.03

TPI 2021; 10(3): 223-229

(C) $2021 \mathrm{TPI}$

www.thepharmajournal.com

Received: 10-01-2021

Accepted: 19-02-2021

Tejbal Singh

Research Scholar in Department

of Agronomy, Institute of

Agriculture Science, Banaras

Hindu University, Varanasi,

Uttar Pradesh, India

Priyanshu Singh

Research Scholar in Department

of Horticulture, Institute of

Agriculture Science, Banaras

Hindu University, Varanasi,

Uttar Pradesh, India

\section{Archit Singh}

Research Scholar in Department

of Horticulture, Institute of

Agriculture Science, Banaras

Hindu University, Varanasi,

Uttar Pradesh, India
Corresponding Author:

Priyanshu Singh

Research Scholar in Department

of Horticulture, Institute of

Agriculture Science, Banaras

Hindu University, Varanasi,

Uttar Pradesh, India

\title{
Silicon significance in crop production: Special consideration to rice: An overview
}

\section{Tejbal Singh, Priyanshu Singh and Archit Singh}

DOI: $\underline{\text { https://doi.org/10.22271/tpi.2021.v10.i3d.5776 }}$

\section{Abstract}

Elemental silicon $(\mathrm{Si})$ is the second most abundant element in the earth's crust after oxygen, which is mainly composed of silicates. Si is not considered essential nutrient for plant growth and development, however, increasing evidences in the literature shows that this metalloid is beneficial to plants, especially under different stress conditions. However, silicon is now comprises important place in the group of beneficial plant nutrient and comes with cobalt, sodium and vanadium, many growers already include it in their crop fertility programs. Silicon plays a crucial role in reinforcing the plant's cell wall and it is speculated that it enable the plants to increased resistance against pests and diseases, increased tolerance to drought and heavy metals, as well as increasing both crop quality and yields.. The amount of Si present in soils varies with the type of soils, climatic conditions, nature of rocks and minerals forming soils etc. The prevailing form in soil solutions is mono silicic acid $\mathrm{Si}(\mathrm{OH})_{4}$, which is in equilibrium with quartz $\left(\mathrm{SiO}_{2}\right)$ and the concentrations in the soil solution are usually ranging from 14 to $20 \mathrm{mg} \mathrm{l}^{-1}$. The crops like rice and sugarcane are known as silicon accumulator and having special significance as well as crops benefited from silicon nutrition.

Keywords: Silicon, abiotic stress, rice, nutrition

\section{Introduction}

Silicon $(\mathrm{Si})$ is a principal soil component lost during weathering and the conversions of $\mathrm{Si}$ to secondary minerals are most important mechanisms of soil formation. The amount of Si present in soils varies with the type of soils, climatic conditions, nature of rocks and minerals forming soils etc. In soil solutions, the prevailing form is mono silicic acid $\operatorname{Si}(\mathrm{OH})_{4}$, which is in equilibrium with quartz $\left(\mathrm{SiO}_{2}\right)$ and the concentrations in the soil solution are usually ranging from 14 to $20 \mathrm{mg} \mathrm{l}^{-1} \mathrm{Si}$ (Devanur, 2015) ${ }^{[7]}$. However, the Si concentration of plant shoots varies greatly among plant species, ranging from 0.1 to $10 \% \mathrm{Si}$ on a dry weight basis. Si is not considered as an essential element, but is a beneficial element for crop growth, especially for Poaceae crops. Silica strengthens the plant, protects the plants against insect pests, increases crop production and quality, increases plant nutrition and neutralizes heavy metal toxicity in acid soils. Plants vary widely in their capacity to take up silicon. Due to continuous monocropping and/or intensive cultivation of cereal crops like rice, the soil $\mathrm{Si}$ concentration is depleted which can be the main reason for declined rice yields (Mali et. al., 2008) ${ }^{[3]}$.

Rice is a staple crop for over half of the world's population and it is grown on nearly every continent that accounts for more than $22 \%$ of world's population calorie intake, with Asia and Africa as the largest consuming regions [Wails et al., 1971]. For the third consecutive year, rice consumption was reported to exceed production, and ending stocks in 2015/2016 are expected to decline $15 \%$ from a year earlier, the lowest global ending stocks since 2007/2008 [USDA, $20152{ }^{[57]}$. Climate changes such as extreme weather, unexpected temperature and rainfall fluctuations have affected crop productivity [Georgescuet al., 2011, Lobellet al., 2011] $[13,30]$. Abdullah $(2015)^{[1]}$ reported that a $1{ }^{\circ} \mathrm{C}$ increase in daily average temperature in the peninsular nation of Malaysia might reduce rice yield by $10 \%$. In addition, according to Tao et al., [2008] [56], rice yield reduction would range from $6 \%$ to $19 \%, 14 \%$ to $32 \%$ and $24 \%$ to $40 \%$ for global mean temperature increase of 1,2 and $3{ }^{\circ} \mathrm{C}$, respectively. Other negative effects were also noted for atmospheric carbon dioxide $\left(\mathrm{CO}_{2}\right)$ concentration of $400-800 \mathrm{ppm}$ and precipitation fluctuations of $14 \%$ [Masud et al., 2014] [34]. An effective soil nutrient management is an essential component of crop production, responsible for increasing and sustaining crop yield at high levels. 
All plant-essential nutrients already have established fertilization programs for rice, except the micronutrients chloride $(\mathrm{Cl})$, manganese $(\mathrm{Mn})$, molybdenum (Mo), and nickel $(\mathrm{Ni})$, that might be supplied through impurities or composition of common-applied fertilizers [Doberman et al., 2009] [8]. Interestingly, silicon is the only one non-essential nutrient that is included in the guidelines for rice fertilization (Si) [Doberman et al., 2009] [8]. Silicon plays an important role in the mineral nutrition of plants, especially for the high accumulator species, such as rice. Its benefits includeenhancing plant defense response against diseases [Rodrigues et al., 2015] [47], protecting plants against insect pests [Hunt et al.,2008] [18], increasing plant photosynthesis and growth [Gong et al., 2005] [14], preventing lodging [Epstein et al., 1991] [9], alleviating water [Agarie et al., 1998] [2] and mineral toxicity stresses [Horiguchi et al., 1988 and Savant 1997] [17, 51-53] and improving fertilizer use efficiency [Friesen et al., 1994] ${ }^{[10]}$.

Rice is a typical silicon accumulator because of the high capability of its roots to take up Si from soil (Mitani\& Ma, 2005). Silicon is an important beneficial nutrient for healthy and competitive growth of all cereals including rice (Bruningset al., 2009). Beneficial nutrients are equally important as macronutrients like nitrogen and phosphorus (Ahmad et al., 2013) [3], and balancing these nutrients in rice cultivation can enhance the quality and yield of the crop (Ma, 2004). Thus, many studies have investigated the functions and mechanisms of $\mathrm{Si}$ in terms of plant pathology, plant physiology, as well as soil science and plant nutrition. Several studies have indicated that continuous rice cultivation affects the silica content of soil. Darmawan et al.,(2006) reported that the average content of available Si decreased from $707 \pm 269$ to $575 \pm 260 \mathrm{~kg} \mathrm{ha}{ }^{-1}$ in the $0-20-\mathrm{cm}$ soil layer and from $3,121 \pm 1,668$ to $2,755 \pm 1,576 \mathrm{~kg} \mathrm{ha}^{-1}$ in the $0-100$-cm soil layer between 1970 and 2003, especially in the upper paddy fields.
Additionally, Husnain et al., (2010) found that long-term fertilisation imbalances in the intensive rice-farming system led to surpluses of nutrients such as $\mathrm{N}$ and $\mathrm{P}$ and deficits of $\mathrm{K}$ and $\mathrm{Si}$. This occurred because between 230 and $470 \mathrm{~kg} \mathrm{ha}^{-1}$ of $\mathrm{Si}$ was removed during rice harvest, while only $75-120,20$ 25 , and $23-257 \mathrm{~kg} \mathrm{ha}^{-1}$ of $\mathrm{N}, \mathrm{P}$, and $\mathrm{K}$, respectively, were removed (Yoshida et al.,1981; Dobermann et al., 1996a,b; Casman et al., 1997) ${ }^{[61,62]}$. A lack of Si available to plants may have adverse effects on rice yield by decreasing resistance to lodging, diseases and pests (Winslow, 1992) ${ }^{[10]}$. In South and Southeast Asia, where most of the world's rice is grown, the straw and husks are typically removed from the field and used for various purposes, including animal fodder, fuel for stoves or burning (Savant et. al., 1997) ${ }^{[51-53]}$. Since most Si taken up by rice is found within the straw and husk, the removal of rice straw accelerates soil desilication with no return of Si via bio-cycling (Seyfferth et al., 2013). There is the considerable importance of silicon in rice production can be studied under following heads:

\section{Silicon in soils}

In the soil solution, $\mathrm{Si}$ is present as Monosilicic acid and Polysilicic acid as well as complexes with organic and inorganic compounds such as aluminium oxides and hydroxides. While it is the PAS (plant available silicon) that is taken up by the plants and has a direct influence on crop growth. The solubility of $\mathrm{Si}$ in the soil is affected by a number of dynamic processes occurring in the soil including the particle size of the Si fertilizer, the soil acidity $(\mathrm{pH})$, organic complexes, presence of aluminium, iron and phosphate ions, temperature and exchangeable/dissolution reactions. Si can be added via irrigation water and fertilization (Berthelsen et al., 2003). Si improves physical, chemical and biological properties of soil.

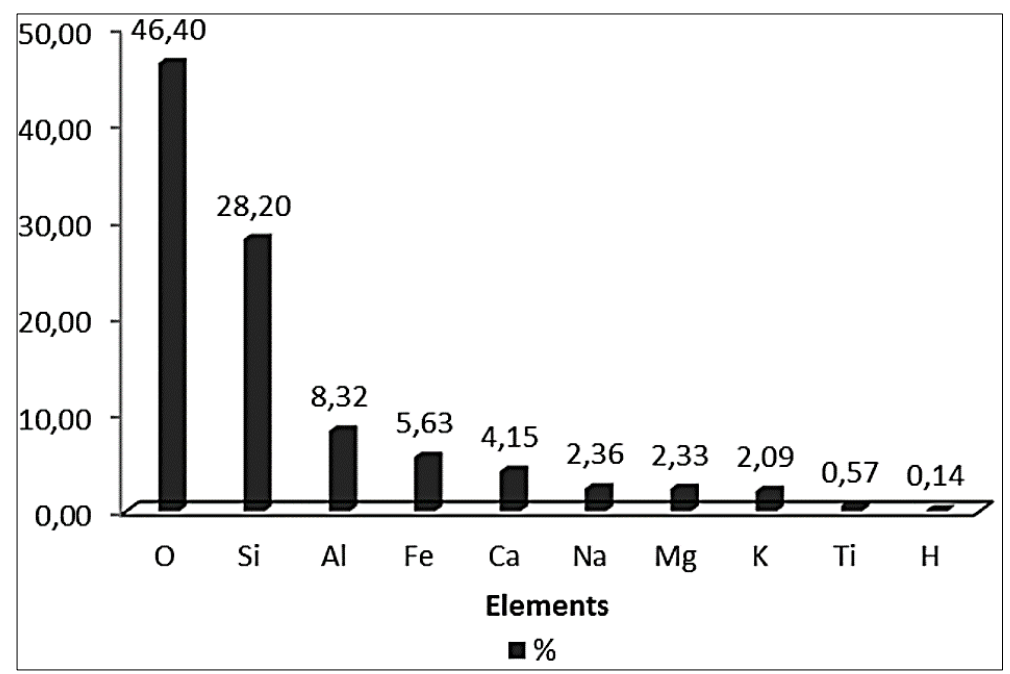

Fig 1: Elements in the earth crust (Adopted from Sharma, 2016) ${ }^{[54]}$

Silicon nutrition of crops: Silicon is the second most abundant element in the earth's crust, with soils containing approximately 32 percent Si by weight (Lindsay, 1979). The essentiality of $\mathrm{Si}$ as a nutrient for higher plants is very difficult to prove because of its ubiquitous presence in the biosphere. Even highly purified water contains about $20 \mathrm{n} \mathrm{M}$ Si (Werner and Roth, 1983). Different species and varieties within species utilize greatly different amounts of $\mathrm{Si}$ from the growth medium (Deren et al., 1994; Aziz et. al., 2001) ${ }^{[50,55] .}$
The plant absorbs Si from the solution in the form of mono silicic acid (H4Si04) which has no electric charge and is not very much mobile in plant (Yoshida, 1975; Savant et al., 1997) ${ }^{[51-53,61,62]}$. Movement of Si follows that of water as the uptake of $\mathrm{H}_{4} \mathrm{SiO}_{4}$ is nonselective and energetically passive and its transport from root to shoot is in the transpiration stream in the xylem (Jones and Handreck, 1965). In rice, however, large amount of $\mathrm{Si}$ in leaves cannot be fully explained by the passive uptake (Savant et al., 1997) ${ }^{[51-53]}$ and may be active 
by gaining energy from the anaerobic respiration (van del' Vorrn, 1980), Silicon deposited in the walls of epidermal cells after absorption by plants, contributes considerably to stem strength.

In relation to plant structure, it was explained by Taiz and Zeiger (2002) that silicon is found at different concentrations within plant tissue and it improves growth and fertility of plants. Primarily, silicon is founded in the endoplasmic reticulum, cell walls (Raven, 2003) and intercellular spaces. As an easily understandable mechanism, it has important role in the support of cell walls by forming complexes with polyphenols. Moreover, silicone reduces the adverse toxic effects of heavy metals. After silicon application, leaves would stand up and benefit from sunlight more efficiently. So, plant performs better photosynthesis and more production (Ding et al., 2007). Silicon stored in the bulliform cells and dumbbell cells improves the strength and rigidity of cell wall, and accordingly increases the resistance of rice to diseases, pests, and lodging (Epstein, 1999; Jones, 2012) ${ }^{[9]}$. Especially bulliform cell are located near the midrib on grass leaf such as rice. The cell group affects leaf folding and, leaves are less exposed to sunlight during drought (Mauseth, 2017).

\section{Role of silicon in rice}

- Rice is a high silicon accumulating plant and the plant is benefited from Si nutrition. Rice crop can uptake Silicon in the range of $230-470 \mathrm{~kg} \mathrm{ha}^{-1}$. Si is a beneficial element for plant growth and is agronomically essential for improving and sustaining rice productivity. Besides rice yield increase, Si has many fold advantages of increasing nutrient availability ( $, \mathrm{P}, \mathrm{K}, \mathrm{Ca}, \mathrm{Mg}, \mathrm{S}, \mathrm{Zn}$ ), decreases nutrient toxicity $(\mathrm{Fe}, \mathrm{Mn}, \mathrm{P}, \mathrm{Al})$ and minimizing biotic and abiotic stress in plants (Ma et al.,2008). Hence, the application of Si to soil or plant is practically useful in laterite derived paddy soils, not only to increase yield but also to alleviate the iron toxicity problems.
- $\quad \mathrm{Si}$ increases the mechanical strength of the culm, thus reducing crop lodging (Savant et al., 1997) ${ }^{[51-53]}$. Silicon nutrition was found to benefit the rice seedlings in nursery by increasing the biomass, dry matter and by keeping the seedlings strong and healthy (Savant et al., 1994) [51-53].

- The number of leaves, tillers and panicle, number of spikelets, grain weight and yield were increased due to silicon fertilizationin both lowland and upland rice (IRRI, 1965; Liang et al., 1994) [21].

- They also observed an increase in water use efficiency in $\mathrm{Si}$ amended rice plants probably due to prevention of excessive transpiration. Disease severity or incidence tends to be reduced with increasing tissue contents of $\mathrm{Si}$ in rice (Datnoff et al., 1990, 91; Osuna-Canizales et al., 1991) $[5,10,47,51,53]$.

- Rice absorbs silicon in the form of ortho silicic acid $\left(\mathrm{H}_{4} \mathrm{SiO}_{4}\right.$ or $\mathrm{Si}\left(\mathrm{OH}_{4}\right)$ along with water by diffusion and also by transpiration induced root absorption by mass flow (Yoshida, 1975) ${ }^{[61,62]}$. But silicic acid present in soil solution is only in the range of $0.1-0.6 \mathrm{mM}(3.5-40$ mg Si $\mathrm{l}^{-1}$ ). Because of continued absorption and transpiration, the silica concentration increases due to loss of water and at higher levels Orthosilicic acid polymerizes into silica gel $\left(\mathrm{SiO}_{2} \cdot \mathrm{nH}_{2} \mathrm{O}\right)$ through a nonenzymatic reaction.

\section{Role of silicon in rice under stress condition}

Silicon can play an important role in overcoming the effects of various environmental stresses (Figure 1). It reduces manganese (Mn), cadmium (Cd), arsenic (As), aluminum $(\mathrm{Al})$, zinc $(\mathrm{Zn})$ and phosphorus $(\mathrm{P})$ deficiency and, increases the resistance to lodging, diseases and insects. Besides, silicon increases plant resistance to abiotic stresses, such as drought and salt stress.

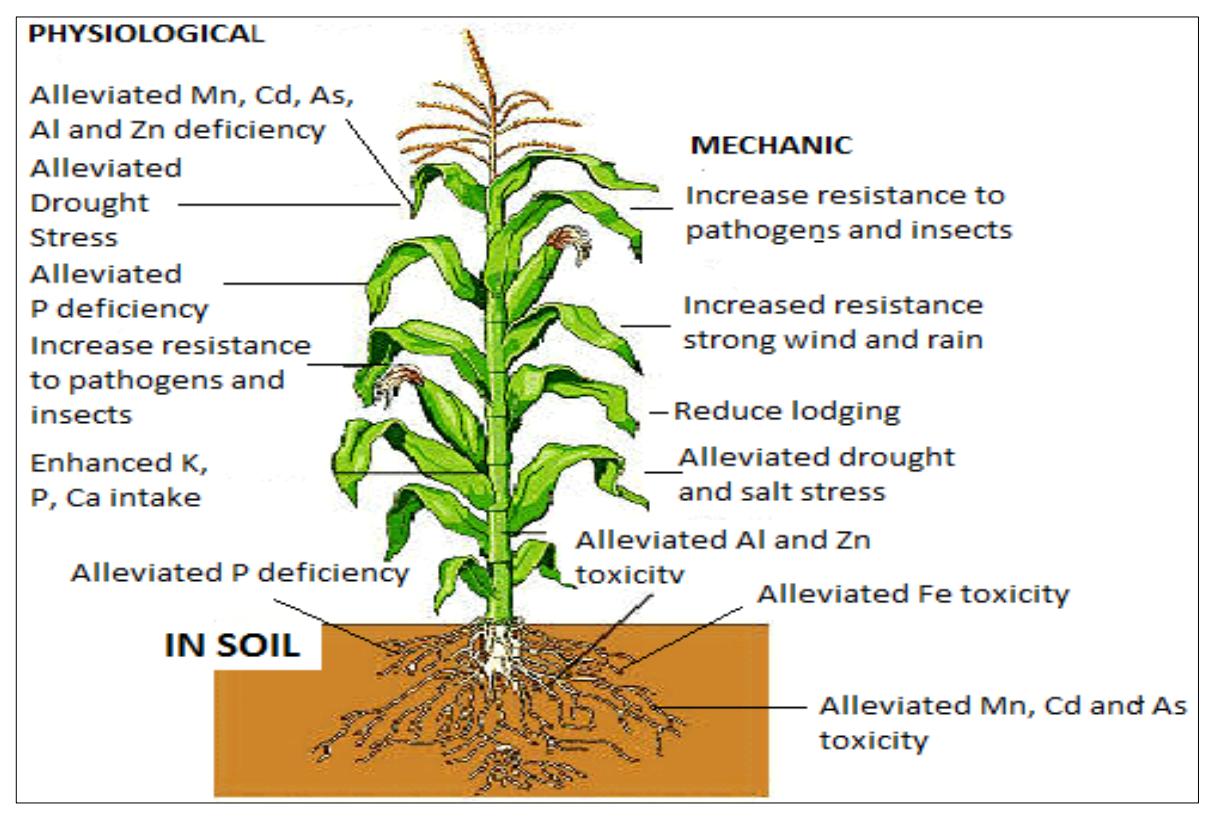

Fig 2: Beneficial effects of silicon [Modified from Mcginnity $(2015)^{[36,37]}$

\section{Silicon role in rice under biotic stress}

The rice plants grown in nutrient solutions containing 0.47 and $47 \mathrm{ppm}$ Si concentration exhibited a difference in the time taken for penetration by the first instar larvae of yellow stem borer, Scirpophaga incertulas. The penetration time increased from 2.8 minutes in plants grown in $0.47 \mathrm{ppm}$ Si to $21.2 \mathrm{~min}$ in plants grown in $47 \mathrm{ppm} \mathrm{Si}$. When seedlings in the nursery was fertilized with silicon through black-grey ash of burnt rice hulls the stem borer damage (dead heart) was reduced in the transplanted rice. The incidence of stem maggots, green 
leaf hopper, brown plant hopper and white backed plant hopper, leaf folder etc. were reduced due to silicon nutrition. Application of silicon to corn affected the biological development of the Spodoptera spp. Silica accumulation reduces nematode infection and the attack of mites in crop plants. Roots of rice varieties containing high silica was found to resist.

\section{Silicon in disease suppression}

Silicon nutrition suppressed the leaf and neck blast, brown spot, sheath blight, leaf scald, grain discoloration, stem rot and bacterial leaf blight infection in rice (Gangopadhyay and Chattopadhyay, 1975; Winslow,1992; Datnoff and Rodrigues, 2005) $[10,12,47]$. Silicon application at $1000 \mathrm{~kg} \mathrm{ha}^{-1}$ through calcium silicate reduced neck blast by $30.5 \%$ and brown spot by $15.0 \%$ over the control (Datnoff and Rodrigues, 2005) ${ }^{[47]}$.

\section{Silicon in alleviating abiotic stress}

Silicon nutrition alleviates many abiotic stresses including physical stress like lodging, drought, UV radiation, high temperatures, freezing and chemical stress like salt, metal toxicity, nutrient imbalance (Epstein, 1994; Ma and Yamagi, 2006) ${ }^{[9]}$.

\section{Silicon nutrition and mitigation of the abiotic-stress in rice crop}

\section{Physical stress}

Lodging, Drought, High temperature, Freezing, UV Radiation etc.

\section{Chemical stress}

Salinity-Rice, Al toxicity- Rice, Fe toxicity- Sugarcane

- Si may increase salinity tolerance to plants by improving water status, increased photosynthetic activity, stimulation of antioxidant system, by reducing salt uptake and increasing K uptake (Tahir et al., 2006) ${ }^{[55] .}$

- The hydrophilic nature of silica could retain more water, dilute salts and protect tissues from physiological drought (Romero-Arnada et al., 2006) [48]. Lodging, a phenomenon of succulence and tender growth due to increased nitrogen supply and water logging is also off set by silicon nutrition (Idris et al., 1975) ${ }^{[19]}$.

- Silicon nutrition increases the antioxidants and the enzymes involved in detoxification of the free radicals. Copper toxicity in plants enhances the phenylalanine ammonia lyase (PAL) similar topathogenic invasion. Silicon nutrition increases phenolic compounds in plants which form silicon phenol complexes that may reduce PAL activity in copper stressed plants (Li et al., 2008).

\section{Silicon nutrition in agricultural crops}

The response of crops to silicon application particularly rice and sugarcane have been extensively investigated both in solution and soil culture (Padmaja and Verghese, 1972) ${ }^{[49]}$. The oxidizing power of rice roots and accompanying tolerance to high levels of iron and manganese was found to be dependent on silicon nutrition. By maintaining a higher root oxidase activity and by decreasing the slowdown of its activity at later stages of growth through silicon, a healthy crop and a higher yield could be achieved (Yuan and Chang, 1978). Supplemental silicon has been proved to be beneficial when silica concentration falls below $1 \%$ in straw and to avoid this problem silicon bearing materials have been recommended for field application (Tisdale et al., 1985).
Application of silicate to rice was found to increase the grain yield under both upland and water-logged conditions (Datta and Shinde, 1985) ${ }^{[6]}$. The application of silicate not only augmented its absorption by rice plant but had a significant interrelationship with the other nutrients as well. With adequate silicon, the uptake of nitrogen was increased (Okamoto, 1969; Sadanandan and Verghese, 1969) ${ }^{[42,49] .}$ However, a decrease in nitrogen content was also reported in rice in response to silicon addition to solution culture (Islam and Saha, 1969) ${ }^{[23]}$. Realizing the agronomically beneficial nature of silicon, silicate minerals, ashes from furnaces and slags from smelters have been used as soil amendment/conditioner to enhance crop yield. Justus von Leibig (1840) ${ }^{[24]}$ suggested the use of sodium silicate as a silicon fertilizer as early as in 1840 and conducted greenhouse experiment with sugar beet. A field experiment started in 1856 in Rothamsted Experiment Station and continued beyond a century and a half revealed the favourable effect of silicates on grass productivity. Further, foliar application effect of silicon on wheat production was conducted in Iran (Maghsoudi et al., 2015) ${ }^{[32]}$ quoted that foliar application of 6 $\mathrm{mM}$ sodium silicate at various stages of wheat growth achieved higher resistance to drought by maintaining cellular membrane integrity, relative water content, and increasing chlorophyll content. White et al., (2017) ${ }^{[16,60]}$ noted highest positive influence of silicon application at tillering and anthesis stages. Si application recorded higher grain yield, number of spikes per square meter, and number of grains per spike. Positive effect on wheat fertilized with silicate slag especially observed in with high $\mathrm{N}$, and in soil with low $\mathrm{Si}$ plant-availability (White et al., 2017) ${ }^{[16,60]}$. A elaborative study carried out in Poland conducted in 2010/2011$2011 / 2012$, on the use of sea calcite (Herbagreen Basic) in autumn (393 $\mathrm{g} \mathrm{Ca} \mathrm{ha}^{-1}$ and $\left.120 \mathrm{~g} \mathrm{Si} \cdot \mathrm{ha}^{-1}\right)$ at four- to six-leaf growth stages in rapeseed, resulted in significant reduction in the plant height of the apical bud, which could have contributed to better resistance of plants in winter conditions (Artyszaket al, 2016) ${ }^{[3]}$.

\section{Silicon deficiency}

Si deficiency affects the development of strong leaves, stems, and roots and makes the rice plants susceptible to pests and diseases. Si deficiency is common in areas with poor soil fertility, and in old and degraded soils. Its deficiency also seen in organic soils with less Si reserves and also occurs in highly weathered soils in rainfed lowland and upland areas. The critical level of $\mathrm{Si}$ in soil is $40 \mathrm{mg} \mathrm{kg}^{-1}$ and the critical level of $\mathrm{Si}$ in rice (leaf and straw) is 5\%. Silicon deficiency leads to:

1. Soft and droopy leaves which cause lodging and mutual shading.

2. Reduced photosynthetic activity.

3. Reduced grain yields.

4. Increased occurrence of diseases such as blast.

5. Reduced number of panicles and filled spikelets per panicle (IRRI, 2016) ${ }^{[21]}$.

\section{Silicon fertilizers}

Rice is a known silicon accumulator and the plant is benefited from silicon nutrition. In 1955, silicon was first recognized as a fertilizer in Japan and since then 1.5-2.0 $\mathrm{t} \mathrm{ha}^{-1}$ of silicate fertilizer have been applied to silicate deficient paddy soils. As a result, a 5-15\% increase in rice yield has been reported by Savant et al. (1999) ${ }^{[51-53]}$. Silicon is absorbed as PAS (monosilicic acid) by rice plants in far larger quantities than 
the macronutrients, for example, silicon uptake is $108 \%$ greater than Nitrogen $(\mathrm{N})$ uptake. A rice crop producing a yield of $5000 \mathrm{~kg} \mathrm{ha}^{-1}$ removes $230-470 \mathrm{~kg} \mathrm{Si} \mathrm{ha}^{-1}$. In continuous cropping with high silicon accumulator species such as sugarcane, the removal of PAS can be greater than the supply via natural processes releasing it into the soil unless fertilized with silicon (Savant et al., 1997; McGinnity, 2015) [51-53].

\section{Chemical fertilizers}

Inorganic materials such as quartz, clays, micas, and feldspars, although rich in silicon, are poor silicon-fertilizer sources because of the low solubility of the silicon (Meharg et al., 2015). Calcium silicate, generally obtained as a byproduct of an industrial procedure is one of the most widely used silicon fertilizers. Potassium silicate, though expensive, is highly soluble and can be used in hydroponic culture and also applied through foliage.

Table 1: Silicon containing fertilizers or materials

\begin{tabular}{|c|c|}
\hline Name content & Name content \\
\hline Calcium silicate $14-19 \% \mathrm{Si}$, & Calcium silicate $14-19 \% \mathrm{Si}$, \\
$20.2 \% \mathrm{Ca}$ & $20.2 \% \mathrm{Ca}$ \\
\hline Potassium silicate $45 \% \mathrm{Si}, 17 \% \mathrm{~K}$ & Potassium silicate $45 \% \mathrm{Si}, 17 \% \mathrm{~K}$ \\
\hline Sodium meta-silicate $23 \% \mathrm{Si}$ & Sodium meta-silicate $23 \% \mathrm{Si}$ \\
\hline Fine silica $99 \%$ & Fine silica 99\% \\
\hline Fused magnesium phosphate $20 \%$ & Fused magnesium phosphate $20 \%$ \\
$\mathrm{Si}, 20 \% \mathrm{P}, 12 \% \mathrm{Mg}$ & $\mathrm{Si}, 20 \% \mathrm{P}, 12 \% \mathrm{Mg}$ \\
\hline
\end{tabular}

Table 2: Silicon fertilizer recommendation for rice

\begin{tabular}{|c|c|}
\hline Fertilizer recommended dose & Fertilizer recommended dose \\
\hline Fine silica $100 \mathrm{~kg} \mathrm{ha}^{-1}$ & Fine silica $100 \mathrm{~kg} \mathrm{ha}^{-1}$ \\
\hline $\begin{array}{c}\text { Sodium silicate } 250 \mathrm{~kg} \mathrm{ha}^{-1} \\
\text { (foliar application: } 4 \mathrm{ml} / \mathrm{L} \text { ) }\end{array}$ & $\begin{array}{c}\text { Sodium silicate } 250 \mathrm{~kg} \mathrm{ha}^{-1} \\
\text { (foliar application: } 4 \mathrm{ml} / \mathrm{L} \text { ) }\end{array}$ \\
\hline $\begin{array}{c}\text { Potassium silicate } 40-60 \mathrm{~kg} \mathrm{ha} \\
\text { (foliar application: } 5 \mathrm{ml} / \mathrm{L} \text { ) }\end{array}$ & $\begin{array}{c}\text { Potassium silicate } 40-60 \mathrm{~kg} \mathrm{ha}^{-1} \\
\text { (foliar application: } 5 \mathrm{ml} / \mathrm{L} \text { ) }\end{array}$ \\
\hline Calcium silicate $120-200 \mathrm{~kg} \mathrm{ha}$ & Calcium silicate $120-200 \mathrm{~kg} \mathrm{ha}^{-1}$ \\
\hline
\end{tabular}

\section{Organic sources of silicon}

Silicon management agenda includes silicon fertilization and recycling of silicon in rice crop residues. Rice husk, rice husk ash and straw are organic sources of silicon (Sahebi et al., 2015; Liang et al., 2007) ${ }^{[27,28,50]}$. Rice straw hauled away from rice fields and used for various purposes, such as animal feed/bedding, biogas production, or mushroom cultivation, may retain its nutrient value as a source of $\mathrm{Si}$; thus the end products of these uses should be recycled. Composting of rice straw offers a potential way of recycling plant $\mathrm{Si}$, because it reduces the bulk of straw to be handled. Silicon content in rice straw and rice husk ranges from $4-20 \%$ and $9-26 \%$ respectively.

\section{Biofertilizer}

Silicon solubilising bacteria (SSB) is a biological fertilizer based on a selected strain of naturally-occurring beneficial bacteria of the Bacillus genus isolated from a granite quarry. It is used as an effective soil inoculant. It solubilizes silica and provides the plant with strength to tolerate biotic and abiotic stresses and improves its resistance to pest and disease attack. SSB contains spores of the Bacillus mucilaginosus. With the changes occurring in the global environment, the role of Silica will become more and more important for better and sustainable production of the crop. In soil system also the application of silicates released more of phosphorus
(Chinnasami et al., 1978) ${ }^{[4]}$. SSB effectively mobilizes unavailable silica ions present as insoluble silicate complexes and make it assimilable by plants (Muralikannan, 1996) ${ }^{[39]}$.

\section{References}

1. Abdullah MY. Climate Change and Food Security 2007. http://www.undp.org.my/uploads/g_Food_security_MAR DI.pdf (accessed on 3 January 2015).

2. Agarie S, Agata W, Kaufman PB. Involvement of silicon in the senescence of rice leaves. Plant Prod. Sci 1998;1:104-105.

3. Artyszak A, Kuci'nska K. Silicon nutrition and crop improvement: Recent advances and future perspective. In Silicon in Plants; Tripathi, D.K., Singh, V.P., Ahmad, P., Chauhan, D.K., Prasad, S.M., Eds.; CRC Press: London, UK; New York, NY, USA 2016,P297-319.

4. Chinnasami KN, Chandrasekaran S. Silica status in certain soils of Tamil Nadu. Madras Agric. J 1978;65:743-746.

5. Datnoff LE, Synder GH, Korndorfer GH. Elsevier Science, Amsterdam P149-158.

6. Datta NP, Shinde JE. Yield and nutrition of rice under upland and waterlogged conditions. Effect of nitrogen, phosphorus and silica. J Indian Soc. Soil Sci 1985;33:5360.

7. Devanur V. SILICON-Solution for tomorrow, Concept note. Available: $1361 \sim$ International Journal of Chemical Studies 2015. http://www.privilifesciences.com/download/siliconsupple ment. pdf. [25 Dec. 2016].

8. Dobermann A, Fairhurst T. Economics of fertilizer use. In Rice: Nutrient Disorders \& Nutrient Management; Potash \& Phosphate Institute; Potash \& Phosphate Institute of Canada; International Rice Research Institute: Los Baños, Philippines 2000, P50-119.

9. Epstein E. The anomaly of silicon in plant biology. Proc. Natl. Acad. Sci. USA 1991;91:11-17. [CrossRef].

10. Friesen DK,Sanz JI, Correa FJ, Winslow MD, Okada K,Datnoff LE, Snyder GH. Silicon deficiency of upland rice on highly weathered Savanna soils in Colombia. I. Evidence of a major yield constraint.

11. Fry SC. Primary cell wall metabolism: tracking the careers of wall polymers in living plant cells. New Phytologist 2004;161:641-675.

12. Gangopadhyay S, Chattopadhyay SB. Total silica and brown spot disease development of rice under varying levels of nitrogen. Curr. Sci 1975;44:92-94.

13. Georgescu M, Lobell DB, Field CB. Direct climate effects of perennial bioenergy crops in the United States. Proc. Natl. Acad. Sci. USA 2011;108:4307-4312.

14. Gong HJ, Zhu XY, Chen KM. Silicon alleviates oxidative damage of wheat plants in pots under drought. Plant Sci 2005;169:313-321.

15. Gruhn P, Goletti F, Yudelman M. Integrated Nutrient Management, Soil Fertility and Sustainable Agriculture: Current Issues and Future Challenges; IFRPI/FAO Workshop: Rome, Italy 2000.

16. Hodson MJ, White PJ, Mead A, Broadley MR. Phylogenetic variation in the silicon composition of plants. Annals of Botany 2005;96:1027-1046.

17. Horiguchi T. Mechanism of manganese toxicity and tolerance of plants. IV. Effects of silicon on alleviation of manganese toxicity of rice plants. Jpn. J Soil Sci. Plant Nutr 1988;34:65-73. 
18. Hunt JW, Dean AP, Webster RE. A novel mechanism by which silica defends grasses against herbivore. Ann. Bot 2008;102:653-656.

19. IdrisMd, Hossaine MM, Choudhury FA. The effect of silicon on lodging of rice in presence of added nitrogen. Plant and Soil 1975;43:691-695.

20. International Rice research Institute. Annual report. 1963 Los Banos, Laguna, Philippines 1965.

21. IRRI (International Rice Research Institute). [Online]. Silicon deficiency2016. Available: http://www.irri.com [25 DEC.2016].

22. Ishizuka Y. Physiology of the rice plant. Adv. Agron 1971;23:241-315.

23. Islam A, Saha RC. Effect of silicon on the chemical composition of rice plants. Plant \& Soil 1969;30:446458 .

24. Leibig J. Organic Chemistry in Its Application to Agriculture and Physiology. Taylor \& Walton, London 1840.

25. Li J, Leisner SM, Frantz J. Alleviation of copper toxicity in Arabidopsis thaliana by silicon addition to Hydroponic solutions. J Am. Soc. Hort. Sci 2008;133:670-677.

26. Li WB, Shi XH, Wang H, Zhang FS. Effects of silicon on rice leaves resistance to ultraviolet-B. Acta Botanica Sinica 2004;46:691-697.

27. Liang YC, Sun WC, Zhu YG, Christie P. Mechanisms of silicon-mediated alleviation of abiotic stresses in higher plants: a review. Environ. Pollut2007;147:422-8.

28. Liang YC, Ma TS, Li FJ, Fung YJ. Silicon availability and response of rice and wheat to silicon in calcareous soils. Commun Soil Sci. Plant Anal 1994;25:2285-2297.

29. Liu C, Li F, Luo C, Liu X, Wang S, Liu T, Liu X. Foliar application of two silica sols reduced cadmium accumulation in rice grains. $\mathrm{J}$ Hazard. Mater 2009;161:1466-1472.

30. Lobell DB, Schlenker W, Costa-Roberts J. Climate trends and global crop production since 1980. Science 2011;333:616-620. [CrossRef] [PubMed]

31. Ma JF, Yamaji N. Functions and transport of silicon in plants. A review. Cell Mol. Life Sci 2008;65:3049-57.

32. Maghsoudi K, Emam Y, Ashraf M. Foliar application of silicon at different growth stages alters growth and yield of selected wheat cultivars. J Plant Nutr 2015;39:11941203.

33. Mali M, Aery NC. Silicon effects on nodule growth, drymatter production, and mineral nutrition of cowpea (Vigna unguiculata). J Plant Nutr. Soil Sci 2008;171:83540.

34. Masud MM, Rahman MS, Al-Amin AQ, Kari F, Filho WL. Impact of climate change: An empirical investigation of Malaysian rice production. Mitig. Adapt. Strat. Glob. Chang 2014;19:431-444. [CrossRef]

35. Mc Cord JM. The evolution of free radicals and oxidative stress. Am. J Med 2000;108:652-659.

36. McGinnity P. Silicon and its Role in Crop Production 2015, P16. http://www.planttuff.com/pdf [25. DEC2016].

37. Mcginnity P. Silicon and its role in crop production. PHD thesis 2015.

http://planttuff.com/wpcontent/ uploads/2015/12/siliconagricultureiiterature-rvw-1.pdf (Date of Access: 20.03.2017).

38. Meharg C, Meharg AA. Silicon, the silver bullet for mitigating biotic and abiotic stress, and improving grain quality in rice? Environ. Exp. Bot 2015;120:8-17.

39. Muralikannan N. Biodissolution of silicate, phosphate and potassium by silicate solubilizing bacteria in rice ecosystem. M.Sc. (Ag) thesis submitted to Tamil Nadu Agricultural University, Coimbatore 1996, P125.

40. Nayar PK, Mishra AK, Patnik S. Silica in rice and flooded rice soils. I. Effects of flooding on the extractable silica in soil and its relation with uptake by rice. Oryza 1982a;19:34-40.

41. Nayar PK, Mishra AK, Patnik S. Silica in rice and flooded rice soils. II. Uptake of silica in relation to growth of rice varieties of different durations grown in an Inceptisol. Oryza 1982b;19:88-92.

42. Okamoto Y. Effect of silicic acid upon rice plants.9. On growth under high and low temperature of the culture solution. 10. On growth under high and low air temperatures. Proc. Crop Sci. Soc. Japan 1969;38:743752.

43. Perry CC, Keeling-Tucker T. Crystalline silica prepared at room temperature from aqueous solution in the presence of intrasilica bio extracts. Chemical Communications 1998;23:2587-2588.

44. Perry CC, Lu Y. Preparation of silicas from silicon complexes: role of cellulose in polymerisation and aggregation control. Faraday Transactions 1992;88:29152921.

45. Projections for 1997-2010; Arkansas Agricultural Experiment Station Special Report; Arkansas Agricultural Experiment Station: Fayetteville, AR, USA 1997; P177.

46. Prychid CJ, Rudall PJ, Gregory M. Systematics and biology of silica bodies in monocotyledons. The Botanical Review 2004;69:377-440.

47. Rodrigues FÁ, Datnoff LE. Silicon and Plant Diseases, 1st ed.; Springer: Berlin/Heidelberg, Germany 2015, P 67-100.

48. Romero-Arnada MR, Jourado O, Cuartero J. Silicon alleviates the deleterious salt effects on tomato plant growth by improving plant water status. J Plant Physiol 2006;163:847-855.

49. Sadanandan AK, Verghese EJ. Role of silicate on the uptake of nutrients by rice plants in the laterite soils of Kerala. Agric. Res. J Kerala 1969;7:91-96.

50. Sahebi M, Hanafi MM, Akmar ASN, Rafii MY, Azizi P, Tengoua FF et al. Importance of Silicon and Mechanismsn of Biosilica Formation in Plants. Bio. Med. Res. Int. 2015, P16.

51. Savant NK, Snyder GH, Datnoff LE. Silicon management and sustainable rice production. Adv. Agron 1997;58:1245-1252.

52. Savant NK, Korndorfer GK, Datnoff LE, Snyder GH. Silicon nutrition and sugarcane production: A review. J Plant Nutr 1999;22:1853-1903.

53. Savant NK, Snyder GH, Datnoff LE. Silicon management and sustainable rice production. Adv. Agron 1997;58:151-199.

54. Sharma R. Role of Silicon in Alleviating Biotic and Abiotic Stresses in Plants. http://www.slideshare.net/Rakeshsarma7/role-of-siliconinalleviating- biotic-and-abiotic-stresses-in-plants59485514. (Date of Access: 20.03.2017).

55. Tahir Rahamatullah MA, Aziz T, Ashraf M, Kanwal S, Maqsood MA. Beneficial effects of silicon in wheat (Triticum aestivum L.) under salinity stress. Pak. J Bot 
2006;38:1715-1722.

56. Tao F, Hayashi Y, Zhang Z, Sakamoto T, Yokozawa M. Global warming, rice production and water use in China: Developing a probabilistic assessment. Agric. For. Meteorol 2008;148:94-110. [CrossRef]

57. United States Department of Agriculture-Economic Research Service. Rice Outlook/RCS15L/December112015. http://usda.mannlib.cornell.edu/usda/current/RCS/RCS12-11-2015.pdf (Accessed on 18 January 2015).

58. Van Hoest PJ. Rice straw, the role of silica and treatments to improve quality. Animal Feed Science and Technology 2006;130:137-171.

59. Wailes EJ, Cramer GL, Chavez EC, Hansen JM. Arkansas Global Rice Model: International Baseline 1971.

60. White B, Tubana BS, Babu T, Mascagni H, Jr Agostinho F, Datnoff LE et al. Effect of silicate slag application on wheat grown under two nitrogen rates. Plants 2017;6:47.

61. Yoshida S. The Physiology of silicon in rice. Food fertilizer Tech. Centre Technical Bull. No. 251975.

62. Yoshida S, Ohnishi Y, Kitagishi K. Chemical forms, mobility and deposition of silicon in the rice plant. Jpn. J Soil Sci. Plant Nutr 1962;8:107-111. 